\title{
Developing the relationship between reflective practice and social work values
}

\section{Graham Ixer $^{1}$}

\begin{abstract}
Summary: There has been considerable literature published on reflection yet despite this, very little research on reflection and more importantly, understanding on what is reflection. This article looks at the context of reflection in the way it came into the social work education language and how it is now part of established training in both social work and other professions. Yet despite this we are still no further on in understanding the complex nature of reflection. However, in a small-scale research project the key characteristics of moral judgement were identified as essential to the process of reflection. The author looks at the relationship between reflective practice and social work values and concludes with key guidelines for the practice teacher and student. The concept of reflection and in particular, its application to practice, applies across health professions as well as social work.
\end{abstract}

Key words: reflective practice; values; anti-oppressive reflective practice guidelines; knowledge

1.Independent researcher and educator

Address for Correspondence: graham.ixer@gscc.org.uk 


\section{Introduction}

During the 1980s schools of social work were looking for a new nirvana of social work training, particularly the way practice teachers' learning were developed. It appeared that the work of Donald Schon (1983) filled a void that educationalists saw as a way of meeting a new level of competence through his 'reflection in action' concept. Schon had brought educationalists a method of bridging the gap between theory and practice through reflection. Although in critiques of Schon's work, in particular Eraut (1994) and Ixer (1999), was critical of Schon for not identifying what 'reflection in action' was. Schon assumed that reflection already existed as a knowable theory and some how was possible to carry out in practice. This is a major weakness in Schon's theory, a theme other writers have also taken up (Bleakley, 1999). However what Schon did do was to initiate a needed debate on the nature of reflection and how professionals should develop it further? Despite Schon's failure to answer sufficiently, what is the nature of reflective practice, social work and nurse curricula has incorporated reflection as a key element in the learning process.

At the time the regulatory body for social work education took up the 'Schon mantle' and included reflection as a requirement in social work training (CCETSW, 1996), reflection became part of a new social work vocabulary that still exists today. Other professionals such as nursing (ENB, 1994) and health promotion (Verma, 1999, p.39) also included reflection as a core requirement for professional training. A wide variety of different professions saw 'judgement' as an outcome of reflection in action and have incorporated it into their training, for example, medicine (Bok, 1984), architecture (Gurman, 1985), urban planning (Alonzo, 1986), public policy (Wildavsky), journalism (White, 1986), and the ministry (Carroll, 1985).

However, despite a proliferation in the literature on reflective practice, for example, Burns and Bulman (2000), Grimmett and Erikson (1998), Calderhead (1989), Killen (1989), Korthagen and Lagerwarf (1996), Morrison (1995), and Tsang (1998) the debate has not developed any further. For example, the following quotes highlights this problem:

It is difficult to distinguish what is and what is not reflective practice as

8 Journal of Practice Teaching 5(1) 2003, pp.7-22

(C) 2003. Whiting and Birch 
Developing the relationship between reflective practice and social work values

the term has become a conceptual methodological umbrella. (Morrison, 1995, p.82);

Everyone has his or her version of reflective practice. (Feiman-Nemser 1990, p.213)

There is no shared sense of 'reflection' to give direction to future development. (Munby and Russell, 1993, p.431).

What literature does exist fails to incorporate anything other than research from a westernised, northern hemisphere tradition (Tremmel, 1993; Tsang, 1998) argues that it is problematic to use westernised theories to explain reflection without incorporating the cultural and historical differences of service users and patients who may have a background in different traditions. The way we generate knowledge on reflection must come from more emancipatory paradigms rather than solely 'technical-rational' ones (Bleakley, 1999, p.317). By doing this we are more likely to incorporate a wider range of knowledge such as those views held from different values traditions and in particular, those from service users who traditionally do not have their views and experience recognised as legitimate knowledge.

The main contention in the debate thus far is that it is one thing to realise the need to reflect on practice, assuming one knows what it is to reflect, but it is something totally different to know how to reflect. Therefore, when one is reflecting, the individual can first identify the process (e.g. they are doing it), replicate it (e.g. be able to carry it out again) and further develop it (e.g. learn more about how they are reflecting). Although this author developed the debate into new areas of consideration, such as social work values (Ixer, 2000a, 2000c), there is an absence of anything new to say about what is reflection as commented on by Burns and Bulman (2000):

There is an abundance of literature on the subject on critical reflection, however the literature is largely theoretical, speculative or frankly anecdotal and beginning to be repetitive. If they wish to add anything substantive to the topic it is time for new commentators to inject some empirical research into the discourses. (p.20)

Earlier work in Sweden (Korthagen and Wubbels, 1995) attempted

9 Journal of Practice Teaching 5(1) 2003, pp..7-22 @ 2003. Whiting and Birch 
to deal with this by developing characteristics on reflection in teacher education but failed to sufficiently provide the evidence based to satisfy critical peers. Yet the need to reflect as part of professional competence is still as important today as it was during the 'Schon era.' The curriculum for a new social work degree in England (GSCC, 2003) will lay the foundations for social work programmes to incorporate reflective practice, although the specific nature of practice is now part of a larger government project (DoH, 2002) yet to conclude for two years.

Despite substantial existing work and research on reflection and values as separate discourses, the earlier work from this author makes claims that social work values are linked to the way social workers reflect, therefore, values must be considered as a key characteristic of the reflective practice discourse. This article will explore the relationship between reflective practice and social work values and lay down a series of basic guidelines for practice teachers working with students.

\section{Social work values underpinning reflection}

In earlier work (Ixer, 2000a) research on reflection was examined to see whether any significant patterns emerged that would throw light on the nature of reflection. The literature was void of any substantial and serious attempt to identify what is reflection. Moreover, it continued the 'Schon debate' on 'reflection in action' as if it was something already accepted and knowable. This is far from the truth as with time, Schon's work is proving to be unreliable as a basis for understanding reflection. Consequently in earlier research (Ixer, $2000 \mathrm{~b}$ ) a number of students at post-qualifying and qualifying level were included in a study that examined their potential reflection in thought and action. This was carried out through examining written assessed text, observation of students in action with follow-up indepth interviews.

The empirical data revealed a relationship between the way one thinks and acts when reflecting. In essence, it makes tentative links between social work values and reflection. One may argue as many have already (Banks, 1995), that values are an intrinsic part of

10 Journal of Practice Teaching 5(1) 2003, pp.7-22

(C) 2003. Whiting and Birch 
everything human beings do, therefore, they must also be part of reflection, as reflection is intrinsically central to human nature. Such a claim has been made many times by earlier epistemologists, for example, Aristotle in his 'virtuous being' (1850) and Kant in his moral philosophy (in particular, his 1889 Critique of Practical Judgement).

The link between reflection and values only became clear when analysing the data from the empirical study. Existing literature made no mention of either the potential or actual relationship between reflection and values. Given the way social work is currently taught and the tortuous history the Central Council for Education and Training in Social Work went through to maintain social work values dominance in the curriculum, it seems somewhat surprising that values have not been linked to the research on reflection before. The National Organisation for Practice Teaching (NOPT) in its Code of Practice (2000) places as core to its principles, social work values. Therefore one can rightly conclude that a curriculum of social work, fit for purpose and duty, will maintain as primacy the role of social work values. Yet despite the equal emphasis being placed on reflection as a key component to social work competence, social work courses will have their programmes based on national occupational standards where values and reflection are seen separately (TOPSS England, 2002), therefore, will be taught separately.

Issit (1999) in her insightful article on reflection relates reflection to anti-oppressive reflective practice and coins the phrase antioppressive practice; this being something different from antioppressive practice. The former is not only 'doing' anti-oppressive practice, but also transcends the individual one step further by the individual understanding his or her own ethical practice through reflection, therefore achieving anti-oppressive reflective practice. Antioppressive reflective practice is practice that is anti-discriminatory because the practitioner has reflected upon their own values in action, made decisions about their current behaviour from what they have learnt through reflection and adjusted it accordingly for future action. Although it is difficult to establish where the evidence base is for this from Issit's short article, it does make a significant link between values and reflection that so far has been missing in the literature.

The key question has to be that if there is a link between reflection and values, what is the nature of such link? Further substantial research would need to be undertaken to satisfy the critics of this

11 Journal of Practice Teaching 5(1) 2003, pp..7-22

(C) 2003. Whiting and Birch 
however, the following argument presents something for practice teachers and students to think about. This will not necessarily add to knowledge on reflective practice, but will provide a critical framework for challenging the status quo on how social work values are taught.

It is accepted here that there is no one theory of social work values as there is no one theory of reflection so different political paradigms and philosophies will influence the way the reader perceives the following debate. Both reflection and values are contested areas (Ixer, $2000 \mathrm{~b})$. Equally contested is both the theory and practice paradigms of reflection and values (Eraut, 2003).

\section{Integrating values with reflective practice}

What we believe in as being morally right, is inherently part of our normal 'human existence' - all our actions are morally laden, therefore all our actions are at some stage within the cognitive process, personally filtered to test their moral content for potential agreeable moral action. According to Eraut (1994), the way one thinks about intended action just before taking action happens instantaneously. Yet adopting professional values such as social work values means they have to be assimilated with ones' own personal values. This in itself is no easy task as students will do anything to shield their own values when they come into conflict with those needed to pass a course. Learning to pass the course, or what Entwhistle and Ramsden (1983) describe as 'expedient learning', sees the student only doing what is necessary to achieve their objective of passing their assessment. Their learning becomes orientated around strategies for passing assessment rather than learning per se. Such scenarios are problematic and undesirable if one is serious about life long learning or learning that is deep level, or what Cree and colleagues (1998) define as 'transferable learning' in that it is sustained beyond the assessment process.

Employers have been critical of social work training for not being 'fit for practice' due mainly to the inflexible way training is delivered (TOPSS England, 2000). As a result the government has responded by implementing a new three-year degree programme for social work with a 'prescribed curriculum' (DoH, 2002). Practice will be a major part of training where students will have to reflect on their practice.

12 Journal of Practice Teaching 5(1) 2003, pp.7-22 (c) 2003. Whiting and Birch 
How the core values of social work will be implemented remains to be seen because it is not clear what specifically the concept of 'fitness' means as social work practice is changing. With the setting up of a new process for registering social care workers, the General Social Care Council will have a specific idea about 'fitness' meaning 'safe to practise' (GSCC, 2003). Employers will require a different form of 'fitness' in doing the job of social work as it is today. Where the enshrined values of social work are placed in this new world are unclear. Therefore a problem could emerge as the purpose of practising core values has changed but not necessarily the recognition to change the training to reflect this. The new social worker and practice teacher need to debate this and how it affects their own personal values alongside the changing world of professional values between workforce and service regulation.

What is needed is a process that expresses the personal values from individuals in a way that neither threatens their own capitulation nor generates a sense of failure. There has to be no right or wrong way of developing social work values - training of values must take an individualised approach if the outcome of achieving student awareness is to be realised. Anything else will see students adopt the language of values to facilitate their own 'expedient learning' or alternatively, learn the language of 'political correctness' to express contemporary forms of practice and 'fitness to practice' expectations.

Rather than teach and support students' developing social work values in isolation, practice teachers need to integrate the teaching with reflective practice. If the two processes of values and reflection become part of a more holistic integrated approach then the student is more likely to understand the relationship between their own values and any conflict this may have with social work values. By starting where the student comes from one initiates the process from a position that is neither right nor wrong. It allows the student to understand his or her own position without fear of failure. The student is then more likely to shift from a perception of passing the course at whatever cost, to one of discovery and experimentation focussing on personal development and learning. Students will not experience failure as an overwhelming dominance on their course but more positively, engage with their practice teacher in a more authentic and meaningful dialogue on values as they experience them and as they change. However, this places a huge responsibility on practice 
teachers being confident and comfortable with their own value base in the process of facilitating dialogue with the student's value base.

It may be difficult for the practice teacher to expose their personal thoughts to external criticism and as such, the practice teacher and student may collude with avoiding discussing this. If the student is allowed to explore and experiment with values through reflection in an open and non-accusatory relationship with their practice teacher, then the student is emancipated from the shackles of an assessmentorientated experience. The experience becomes learning orientated and gives the student a new type of freedom that will help rediscover their creativity in a way that Julia Philipson (2001) proclaims as a long lost quality of social work.

This of course is not easy; one has to be prepared to take risks. After all social workers expect their clients to take risks everyday in disclosing personal aspects of their lives to them. Students will only take risks if they first, know it is safe to do so in that they will not be penalised, and second, that they are supported by their practice teacher in taking such risks. If students are to learn they need to know that it is safe to experiment.

The way a student and their practice teacher must grapple with the complexities of the inter/intra-personal relationships with theory and practice, is through using reflective practice. Encouraging reflection as a means of exploring values and one's intended moral action will not necessarily achieve the immediate outcome of performing a desired set of social work values in an individual. More importantly, a critical debate is achieved about these values so if the student changes their (moral) position on practice, such change is done with more authenticity and genuineness rather than expediency or political desire.

The student accepts responsibility for their change as they are in control of the learning process, rather than the student being led through coercion by the practice teacher or other. Through the student being given power in their role from the practice teacher, the student is able to challenge them and feel more enabled to experiment with different learning modes and therefore achieve greater success in their own learning. The student is more likely to be open about their challenging values and comfortable about discussing them, as they (the student) have been in control of the change process throughout; the practice teacher's role has been limited (albeit 
essential) to offering a positive critique and support to the student rather than in controlling the relationship. The reflective process helps to achieve learning about values and will be sustained beyond the assessment process. An ambitious claim but one every practitioners must subscribe.

In essence this is not about 'rocket-science', in a way it has already been said by other more wiser writers such as Paulo Friere (1972). He links the relationship between values and reflection with dialogue. Friere formed the term 'conscientisation' which basically means developing consciousness that is understood to have the power to transform reality or multiple realities. To Friere all reality is a social construction and therefore the way we become conscientious of our reality is in the way we build it up for ourselves. The construction is done through dialogue, which gives the learner the power to challenge, and determined for themselves, what and whose values and knowledge matter. Without dialogue, is what Friere sees as oppression. As we reflect and discover different discourses to reject or accept, becomes a liberating experience that leads to empowerment. It is dialogue we must preserve for the student so they can become empowered and therefore, liberated from the chains of prescriptive education. This will then help develop Issitt's 'anti-oppressive reflective practice' (1999).

\section{Guidelines for engaging in anti-discriminatory reflective practice}

The following guidelines have been developed over time through empirical research (Ixer, 2000a), experience of practice and much personal reflection. They are not meant to act as formulae for antioppressive reflective practice, but a framework for debating, critically examining one's own practice and learning. Moreover, they are intended to challenge one's own thinking and acceptance of social work practice and achieve greater confidence in challenging others' practice. They will aid the practitioner to reflect on their practice. By doing this one will gain greater freedom from the constraints of rigid systems of knowledge acquisition and therefore liberate students from the narrowness of performance led learning to more self-ownership

15 Journal of Practice Teaching 5(1) 2003, pp..7-22 (c) 2003. Whiting and Birch 
and control of their own life long learning. Such sentiments can be best stated by the following words of wisdom:

The youths whom I called out in 1920 from those citadels of slavery their schools and colleges - and whom I advised that it was better to remain unlettered and break stones for the sake of liberty that go for literary education in the chains of slaves will probably be able now to trace my advice to its source. (Ghandhi, 1982, p.199)

It is the intention here that unless we understand reflection and its contribution towards practice knowledge in a moral context, then we will never understand professional education, as it will only serve the practice and rehearsal of enslavement. As Ghandhi implies above, insight through reflection is 'the unshackling of educational enslavement'. Helping to develop students' ability to argue, criticise and analyse speedily, synthesise vast amounts of complex information (much of which is morally based), and to formulate moral judgements towards anti-oppressive action, all characterise the holistic process of reflection and moreover, the specific nature of what is reflection. The following are twelve key principal statements that are guidelines relevant to the practice teacher in social work, the mentor in nursing, the fieldwork tutor in occupational therapy and any other professional where reflecting in practice is essential. It will help to guide them to more successful reflection.

\section{Definitions and shared understanding}

1. There is no one theory of reflective practice therefore, the student must discuss with their practice teacher their espoused model, or if not a model, an understanding to ensure there is shared cognisance of reflection so they can work together from the same equal understanding.

2. Research has suggested that reflection has four interrelating characteristics - cognitive, affective, moral and creative (Ixer 2000a). Reflection is not a purely intellectual activity; it also includes feelings (Boud 1986, p.28), values (Brockbank and McGill, 1998, p.58) and potential to innovative beyond social constraints (Tremell, 1993). These should be used and acknowledged when reflecting.

16 Journal of Practice Teaching 5(1) 2003, pp.7-22

(C) 2003. Whiting and Birch 
3. Reflection is a process skill, which allows one to look internally at the way the individual learns and reflects on their own reflection (meta-cognition) - thus developing greater insight on their own practice and thoughts about their practice. Reflection should not be just seen as a means to an end but also an end in itself.

\section{Practice teacher responsibilities}

4. Issues of race, gender, sexual orientation and other social constructs will always be prevalent and should be maintained on the practice teacher's agenda throughout their sessions with the student whether or not both parties have cultural affinity with each other.

5. Reflecting on one's own values is likely to be difficult and even painful and self-discovery can bring many surprises. Encouragement to discuss values is only part of the process therefore, non-judgemental support is crucial. This action should be part of a way of life for the practice teacher, in so doing will ensure greater integration of reflective practice with values.

6. The practice teacher must continually reflect on their practice, reflect on their reflection, monitor their reflection and analyse the outcome of their reflection so new learning can be identified and shared with others. Moreover, reflective practice can lead to changes in future practice as new techniques, skills and understanding are internally absorbed. They will need a mentor to help them with this.

7. The essence of integrating values with reflection is to encourage open and critical dialogue; this will help to construct authentic realities for the student rather than artificial ones for the benefit of the practice teacher. The practice teacher should always engage in open dialogue with their student a part of developing themselves as well as the student.

\section{Creating a trusting climate for learning}

8. The success of the student will rely on the degree of openness between them as the learner and their practice teacher as mentor,

17 Journal of Practice Teaching 5(1) 2003, pp..7-22 (c) 2003. Whiting and Birch 
supporter, assessor or tutor. A way of measuring this can be determined by the degree of personal disclosure by both parties on values.

9. The student will only reflect on their values and take responsibility for personal development if they feel safe, supported and the risk is worthwhile. Alternatively the student will only learn to give the practice teacher what they want to hear and achieve 'expedient learning.' The practice teacher should be clear about how they will facilitate this.

\section{Techniques to encourage and evaluate reflection}

10. Engaging in reflection should be seen as a process in itself as well as developing competence in practice. Allowing the student to indulge in reflection and learn from the experience, away from performing to set criteria and assessment, frees up the student to explore and experiment without the pressure of assessment. Students should be encouraged to do this.

11. There are many ways to encourage and aid reflection. Using narrative as a method can be helpful. It can be useful to encourage the student to tell their story about their values in the context of its history rather than current practice. Use the third person if this is more helpful. This may help to identify the extent of development required in the student.

12. The process of developing values through reflection is not about the practice teacher disclosing their own values and requiring the student to model themselves on this, but rather, to allow the student to explore and identify for themselves their own values. Through this process the student is more likely to discuss their own values alongside social work values and commit themselves to areas of development and change. There has to be a true commitment to change fro the student is authentic change is to be.

13. Reflection can be best measured by evaluating the degree to which the student can clearly articulate their own reflection on reflection and describe the process as well as outcomes emerging. This is likely to include cognitive, moral, affective and creative content. Ask the student to evaluate their own reflection.

18 Journal of Practice Teaching 5(1) 2003, pp.7-22

(C) 2003. Whiting and Birch 
By doing this learning will be demanding but more importantly, rewarding and fun, then perhaps the dialogue about reflection and values will more successfully become integrated.

Professional educators must no longer consider the area of reflection as a knowledge domain that stands in isolation to the values of social work, nursing, or other professions. They must go side by side, separate but dependent upon each other. Teaching and developing values in students must equally be seen as essential to learning how to reflect in practice.

\section{In conclusion}

Reflection is a problematic area of knowledge construction. What we know and understand is contested with no reliable substantial research supporting particular hypotheses. Until such time that we are able to learn more about its nature, characteristics and meaning, the author takes a pragmatic approach and urges practice teachers to clarify for themselves, a working understanding that is clearly communicated to their student. A set of guidelines is developed here to help the practice teacher think about how they might go about formulating this understanding.

\section{References}

Alonzo, W. (1986) The unplanned paths of planning schools. The Public Interest, 82, 58-71

Aristotle (1850) The Nicomachean Ethics. trans. R.W. Bourne. London: H.G. Bohn

Banks, S. (1995) Ethics and Values in Social Work. Basingstoke: Macmillan Bleakley, A. (1999) From reflective practice to holistic reflexivity. Studies in Higher Education, 24, 3, 315-330

Bok, D. (1984) Needed: a new way to train doctors. Harvard Magazine, May-June, 32-43

Boud, D., Keogh, R., and Walker, D. (1985) What is reflection in learning?

19 Journal of Practice Teaching 5(1) 2003, pp..7-22 (c) 2003. Whiting and Birch 
in D.Boud et al. (eds) Reflection: Turning experience into learning. London: Kogan Page (pp.7-40)

Brockbank, A., and McGill, I. (1998) Facilitating Reflective Learning in Higher Education. Buckingham: Society for Research into Higher Education/Open University Press

Burns, S., and Bulman, C. (2000) Reflective Practice in Nursing. (2nd edition) Oxford: Blackwell Science

Calderhead, J. (1989) Reflection teaching and teacher education. Teachers and Teaching Education, 5, 1, 43-51

Carroll, J.W. (1985) The professional model of the ministry: It is worth saving?, Theological Education, 21, 7-48

CCETSW (1996) Assuring Quality for the Diploma in Social Work - 1. London: Central Council for Education and Training in Social Work

Cree, VE, Macaulay, C and Loney, H (1998) Transfer of Learning: A study. Edinburgh: The Scottish Office Central Research Unit and the Central Council for Education and Training in Social Work

DoH (2002) New Social Work Reform will focus on Practical Training. Ministerial Press Release, 2002/0241. London: Department of Health

English National Board for Nursing, Midwifery and Health Visiting (1994) Creating Lifelong Learners' Partnerships for Care: Guidelines for midwifery and nursing programmes of education to registration. Cottenham, Cambs: Jill Rogers Associates/ENB

Entwistle, N. and Ramsden, P. (1983) Understanding Student Learning. London: Croom Helm

Eraut, M. (2003) The Many Meanings of Theory and Practice. Learning in Health and Social Care, 2, 2, 61-65

Eraut, M. (1994) Developing Professional Knowledge and Competence. London: Falmer Press

Feiman-Nemser, S. (1990) Teacher preparation: Structural and conceptual alternatives. in W.R. Houston (ed) Handbook of Research on Teacher Education. New York: Macmillan (pp.212-233)

Friere, P. (1972) Pedagogy of the Oppressed. London: Sheed and Ward

Gandhi, M.K. (1982) M.K. Gandhi: An autobiography of the story of my experiments with truth. London: Penguin

GSCC (2003) Opening the Social Care Register. News item on the General Social Care Council's website - www.gscc.org.uk

Grimmett, P.P. and Erikson, G.L. (1998) Reflection in Teacher Education. New York: Teachers College Press

Gurman, R. (1985) Educating architects: Pedagogy and the pendulum. The

20 Journal of Practice Teaching 5(1) 2003, pp.7-22

(C) 2003. Whiting and Birch 
Developing the relationship between reflective practice and social work values

Public Interest, 80, 67-91

Issitt, M. (1999) Toward the development of anti-Oppressive reflective practice: The challenge for multi-disciplinary working. The Journal of Practice Teaching in Health and Social Work, 2, 2, 21-36

Ixer, G.W. (1997) The reflective competent. in CCETSW (ed.) Learning for Competence. London: Central Council for Education and Training in Social Work

Ixer, G.W (1999) There's no such thing as reflection. British Journal of Social Work, 29, 513-527

Ixer, G.W. (2000a) Assumptions about reflective practice: Towards a more sustainable approach. in J. Harris, L. Froggett and I. Paylor (eds.) Reclaiming Social Work: The Southport Papers, 1. Birmingham: Venture Press

Ixer, G.W. (I2000b) 'Assessing Reflective Practice: New Research Findings' - paper Presented to the National Conference for Practice Teachers -Self-assessment: making it work in practice, $11^{\text {th }}$ July Bristol University and Annual conference for Practice Teachers at UMIST Manchester 22-23 June 2000

Ixer, G.W. (2000c) Assessing reflective practice: New research findings. Journal of Practice Teaching in Health and Social Work, 2, 3, 19-27

Kant, I. (1889) Critique of Practical Reason and other works and the theory of ethics. [trans. T.K. Abbott] London: Longman

Killen, L. (1989) Reflection on Reflective Teaching: A response. Journal of Teacher Education, 40, 2, 49-52

Korthagen, F.A. and Lagerwarf, B. (1996) Reframing the relationship between teacher thinking and teacher behaviour: Levels in learning about teaching. Teachers and Teaching: Theory and Practice, 2, 2, 161-190

Korthagen, F.A. and Wubbels, W. (1995) Characteristics of reflective practitioners: Towards an operationalization of the concept of reflection. Teachers and Teaching: Theory and practice, 1, 1, 51-72

Morrison, K. (1995) Dewey, Habermas and reflective practice. Curriculum Inquiry, 16, , 2, 82-94

Munby, H. and Russell, T. (1989) Educating the reflective teacher: An essay review of two books by Donald Schon. Journal of Curriculum Studies, 21, $7,77-80$

NOPT (2000) The Code of Practice for Practice Teachers. Stockport: National Orgaisation for Practice Teachers

Philipson, J. (2001) After Dinner Speech at The Fist European Conference on Practice Teaching. York, England. 13 September

21 Journal of Practice Teaching 5(1) 2003, pp..7-22

(C) 2003. Whiting and Birch 
Schon, D. (1983) The Reflective Practitioner. New York: Basic Books

TOPPS England (2002) National Occupational Standards for Social Work. Key Role 6, 19.4 and 20.3. Leeds: National Training Organisation for Social Care in England

TOPPS England (2000) Modernising the Social Care Workforce: the first national training strategy for England. 2.7.1. Leeds: National Training Organisation for Social Care in England

Tremmel, R. (1993) Zen and the art of reflective practice in teacher education, Harvard Education Review, 63, 4, 434-459

Tsang, N.M. (1998) Re-Examining Reflection: A common issue of professional concern in social work, teacher and nursing education. The Journal of Practice Teaching in Health and Social Work, 1, 2, 31-47

Verma, C (1999) Developing a culturally sensitive approach to promoting heart disease prevention among UK Asians: An action research approach utilising reflective practice. Journal for Practice Teaching in Health and Social Work, 2, 2, 37-50

White, S. (1986) 'Why journalism schools? The Public Interest, 82, 39-57

Wildavsky, A. (1985) The once and future school of public policy. The Public Interest, 79, 25-41 